\title{
Audit Committee, Foreign Ownership and Sustainability Report
}

\author{
Makhdalena \\ Faculty of Pedagogical and Education Science, Universitas Riau, Pekanbaru, Indonesia
}

\begin{abstract}
The purpose of this study is to see whether the audit committee and foreign ownership influence the sustainability report with leverage, size and independent commissioners as control variables. The population of this study are mining companies listed on the Indonesia Stock Exchange and have complete data on audits, independent commissioners, foreign ownership, size and leverage for the period 2012 - 2015. Data analysis techniques in this study used multiple regression with the help of SPSS. The results of the study indicate that audit committee does not involve sustainability report, while foreign ownership is considered negative for sustainability report.
\end{abstract}

Keywords: audit committee, foreign ownership and sustainability report.

DOI: $10.7176 /$ RJFA/10-4-03

\section{Introduction}

According to Berle and Means (1932) the company is a system in society. Where the system consists of several components, namely investors, employees, creditors, consumers, suppliers, government and society where these components are also called stakeholders. In order for the company to survive, the company has to pay attention to the interests of stakeholders (Berle and Means, 1932). Furthermore, Elkington (1997) with The Triple Bottom Line theory said that to be survived, the company not only pay attention to stakeholders, but also planet in addition to profit and people. This is called by sustainability or corporate social responsibility. In fact, many companies do not pay attention to sustainability. Evident from the many cases that occurred in the world giant companies that went bankrupt and harmed the stakeholders include: Enron Corporation, Consesco, and WorldCom in the United States, Baring Futures in Singapore and Peregrime Investment Ltd in Hong Kong, Lehman Brother and Toshiba. An accounting scandal also occurred with BP Migas which caused State losses of Rp. 16.1 trillion (Tempo, 19 November 2012). An accounting scandal also occurred with Real Gold Mining and Sky China Petroleum service Ltd (Reuters.com, October 13, 2011). Whereas cases of environmental pollution (planet) and tribal empowerment occur in Papua by Freeport companies (Liputan6, 2016). Pollution also occurs in the Timor Sea and a lawsuit has been made by the government against the Australian EP PTT over an explosion incident in oil and gas fields which has caused oil pollution in the waters of the NTT Timor Sea (Tempo, March 18, 2017). Lapindo mudflow in Porong, environmental pollution by Newmont in Buyat bay.

Companies have to pay attention to sustainability in order to get survived (Elkington, 1997). To make the company pay attention to sustainability, it is necessary to have an audit committee (Khan et al, 2012; Jizi et al, 2014; Kend, 2015; Said et al, 2017) and the existence of foreign ownership (Darus et al, 2009; Said et al, 2009; Saleh et al, 2010; Oh et al, 2011; Khan et al, 2013; Soliman et al, 2013; Guinness et al, 2017). Based on the formulation of the problem in this study is: Are the audit committee and foreign ownership influencing sustainability report on mining companies listed on the Indonesia Stock Exchange? The purpose of this study is to see whether the audit committee and foreign ownership influence the sustainability report of mining companies listed on the Indonesia Stock Exchange.

\section{Literature Review}

\subsection{Conceptual Framework}

\subsubsection{Sustainability Report}

Sustainability report is a report that contains financial and non-financial performance information, which concerns environmental, social and economic issues that enable companies to grow sustainably (Elkington, 1997). Sustainability Accounting Standard, disclosure indicators are divided into 11 groups, namely: emissions of greenhouse gas, quality of water, management of energy, water and hazardous materials, biodiversity impacts, community relations, security, human rights and rights of indigeneous people, workforce health, safety and wellbeing, labor relations, business ethics \& payments transparency. And from these 11 groups it was translated into 22 items (SASB, 2014). There are several factors that can influence sustainability report, they are Audit Committee (Said et al 2017; Said et al, 2009; Khan et al, 2013; Jizi et al, 2014; Kend, 2015) and Foreign Ownership (Guinness et al, 2017; Said et al,2009; Khan et al, 2013; Oh et al, 2011; Soliman et al, 2013).

\subsubsection{Audit Committee}

An audit committee is a part of the board of commissioners who is responsible for the financial reporting process and disclosure (Messier et al, 2006). The indicators of the audit committee are: number of members, number of independent, number of financial experts and number of meetings (Makhdalena, 2012). 


\subsubsection{Foreign Ownership}

Foreign ownership is ownership of company's share by foreign parties either individually or institution (Zulvina et al, 2017). The indicator of Foreign ownership is percentage of foreign ownership (Makhdalena, 2016).

\subsection{Theoretical Framework}

\subsubsection{Audit Committee and Sustainability Report}

One of the factors that influence sustainability report is an audit committee (Said et al 2017; Said et al, 2009; Khan et al, 2013; Jizi et al, 2014; Kend, 2015). Research on the audit committee and sustainability report has been carried out by previous researchers, such as: Said et al (2017); Said et al (2009); Khan et al (2013); Jizi et al (2014); Kend (2015).

Said et al (2017) conducted a study on listed companies in Malaysia using regression as a data analysis tool. The results of the study show that government ownership and audit committees have a positive and significant influence on CSR disclosure.

The research conducted by Said et al (2009) on listed companies in Malaysia using regression as a data analysis tool. It showed that the independent commissioners, government ownership, duality, audit committees, managerial ownership and foreign ownership had a positive and significant influence on corporate social responsibility disclosure.

Khan et al (2013) conducted research on companies listed on the Dhaka Stock Exchange using regression as a data analysis. The results of the study indicate that public ownership, foreign ownership, independent board, audit committee, and CEO have a significant positive impact on CSR disclosure.

Jizi et al (2014) have conducted research on National commercial banks in the US using regression as data analysis. The results showed that the audit committee had a positive relationship with CSR disclosure.

Kend (2015) has conducted research on companies registered in the UK and Australia using Sequential logit analysis data in the analysis of research data. The results show that the audit committee is active and effective in influencing disclosure of voluntary sustainability.

\subsubsection{Foreign Ownership and Sustainability Report}

Research on foreign ownership and sustainability report has been largely carried out by Guinness et al (2017); Said et al (2009), Khan et al (2013), Oh et al (2011), Soliman et al (2013).

Guinness et al (2017) conducted research on companies listing in China. The results showed that CSR scores were increasing in foreign ownership. Darus et al (2009) have conducted research on companies listing in Malaysia by using regression as a data analysis tool. The results showed that foreign ownership has a positive effect on CSR but not significant.

Soliman et al (2013) undertook research on non-financial companies listing on the influence of ownership structure on corporate social responsibility for the 2007-2009 periods by using multiple regressions. The result is that foreign ownership is positively related to CSR.

Khan et al (2013) have listed the Dhaka Stock Exchange for 2005-2009 periods by using regression as an analytical tool. The results showed that foreign ownership had a positive and significant effect on CSRD.

Oh et al (2011) has conducted research on companies listing the Korean Stock Exchange by using regression analysis tools. The results showed that foreign ownership positively affected CSR. The existence of foreign ownership can also increase CSR.

The research conducted by Said et al (2009) on listing companies in Malaysia using regression as a data analysis tool. The results of research conducted by Said et al (2009) showed that the results of independent commissioners, government ownership, duality, audit committees, managerial ownership and foreign ownership had a positive and significant influence on corporate social responsibility disclosure.

\subsection{Research Hypothesis}

Based on the theoretical overview, the research hypothesis is:

H1: Audit committee is positively related to sustainability report.

$\mathrm{H} 2$ : Foreign ownership is positively related to sustainability report.

\section{Research Methods}

This research is quantitative descriptive research. The audit committee (AC) and foreign ownership (FO) as independent variable and Sustainability Report (SR) as the dependent variable. While Size, independent commission (IC) and leverage is as a variable control. Foreign ownership (FO) is either an individual or institution with a percentage of share ownership by foreign ownership. Independent commission (IC) is a representative of minority shareholders and other stakeholders who have a no business and family relationship with a percentage of independent commissioners in the board of commissioners. Sustainability report is a report that involves financial performance information and non-financial information, which concerns environmental, social, and economic issues that enable companies to grow sustainably with the Sustainability Report Disclosure Index. 
Population of this study are mining sector companies listed on the Indonesian Stock Exchange during the research period 2012-2015. However, companies that have complete data (Audit Committee, Foreign Ownership, Independent Commissioners, Size and Sustainability Report) for four (4) consecutive years are only 9 companies and all are taken. The type of data from this research is secondary data obtained by the technique that comes from annual report and sustainability report. The method of data analysis is using path analysis with the help of SPSS.

The detailed operationalization of research variables as follows:

Table 1

Operationalization of Research Variable

\begin{tabular}{|c|c|c|c|}
\hline Variable & Concept & Indicator & Scale \\
\hline $\begin{array}{l}\text { Dependent } \\
\text { Variable: } \\
\text { Sustainability } \\
\text { Report }\end{array}$ & $\begin{array}{l}\text { Report concerning financial performance } \\
\text { information and non-financial } \\
\text { information, namely those concerning } \\
\text { environmental, social, and economic } \\
\text { issues that enable companies to grow } \\
\text { sustainably (Elkington, 1997). }\end{array}$ & $\begin{array}{l}\text { Sustainability Report Disclosure } \\
\text { Index (SASB, 2014). } \\
\mathrm{SRDI}=\mathrm{n} / \mathrm{k}\end{array}$ & Ratio \\
\hline $\begin{array}{l}\text { Independent } \\
\text { Variable: } \\
\text { Audit } \\
\text { Committee }\end{array}$ & $\begin{array}{l}\text { One of the board which is made by } \\
\text { commissioners that responsible for the } \\
\text { financial reporting process and disclosures } \\
\text { (Messier et al, 2006). }\end{array}$ & $\begin{array}{l}\text { Amount of members, amount of } \\
\text { independent members, amount } \\
\text { of financial experts and number } \\
\text { of meetings (Makhdalena, 2012) }\end{array}$ & Ratio \\
\hline $\begin{array}{l}\text { Foreign } \\
\text { Ownership (FO) }\end{array}$ & $\begin{array}{l}\text { Ownership of the company's shares by } \\
\text { foreign parties either individually or } \\
\text { institution. }\end{array}$ & $\begin{array}{l}\text { Percentage of ownership by } \\
\text { foreign }\end{array}$ & Ratio \\
\hline \multicolumn{4}{|l|}{$\begin{array}{l}\text { Control } \\
\text { Variable: }\end{array}$} \\
\hline Size & The size of a company & Total asset & Ratio \\
\hline Leverage & The amount of assets financed by debt & Debt ratio with assets & Ratio \\
\hline $\begin{array}{l}\text { Independent } \\
\text { Commission } \\
\text { (IC) }\end{array}$ & $\begin{array}{l}\text { Representatives of minority shareholders } \\
\text { and other stakeholders who have no } \\
\text { business and family relationship with the } \\
\text { company }\end{array}$ & $\begin{array}{l}\text { Percentage of the number of } \\
\text { independent commissioners in } \\
\text { the board of commissioners }\end{array}$ & Ratio \\
\hline
\end{tabular}

The model of this research is as follows:

$\mathrm{SR}=\mathrm{C}+\beta_{1} \mathrm{AC}+\beta_{2} \mathrm{FO}+\beta_{3} \mathrm{IC}+\beta_{4} \mathrm{Size}+\beta_{5} \mathrm{LEV}+\mathrm{e}$

\section{Results and Discussion}

Tabel 2

Descriptive Analysis

\begin{tabular}{|r|l|r|r|r|r|r|r|}
\hline NO & VARIABLE & \multicolumn{1}{|c|}{ MIN } & \multicolumn{1}{|c|}{ MAX } & \multicolumn{1}{|c|}{ MEAN } & \multicolumn{1}{|c|}{$\begin{array}{c}\text { ABOVE } \\
\text { MEAN } \\
(\%)\end{array}$} & $\begin{array}{c}\text { BELOW } \\
\text { MEAN } \\
(\%)\end{array}$ & $\begin{array}{c}\text { STD. } \\
\text { DEVIASI }\end{array}$ \\
\hline 1 & AC & 6 & 21 & 14.11 & 30.6 & 69,4 & 3.3956 \\
\hline 2 & FO & 10.1 & 97 & 51.57 & 44.4 & 55.6 & 26.977 \\
\hline 3 & SIZE & 2.61 & 8.59 & 1.51 & 75 & 25 & 2.0694 \\
\hline 4 & LEV & 0.16 & 40 & 3.48 & 11.1 & 88.9 & 9.58 \\
\hline 5 & IC & 30 & 60 & 38 & 41.7 & 58.3 & 7.7012 \\
\hline 6 & SR & 4.55 & 68.18 & 32.07 & 44.6 & 55.6 & 15.2098 \\
\hline
\end{tabular}


Tabel 3

Descriptive Analysis of Audit Committee

\begin{tabular}{|c|l|r|r|r|r|}
\hline NO & VARIABLE & \multicolumn{1}{|c|}{ MIN } & \multicolumn{1}{c|}{ MAX } & MEAN & $\begin{array}{c}\text { STD. } \\
\text { DEVIASI }\end{array}$ \\
\hline 1 & SIZE & 2 & 4 & 2.97 & 0.2914 \\
\hline 2 & IND & 2 & 4 & 2.92 & 0.3683 \\
\hline 3 & EXP & 0 & 3 & 1.78 & 0.8655 \\
\hline 4 & MEETING & 0 & 13 & 6.44 & 3.0184 \\
\hline
\end{tabular}

Tabel 4

Audit Committee, Foreign Ownership and Sustainability Report in Mining Companies Listed on Indonesia Stock Exchange

\begin{tabular}{|l|c|c|c|}
\hline \multicolumn{1}{|c|}{ Variabel } & Standardzed Coef (r) & R ( $\left.\mathbf{r}^{\mathbf{2}}\right)$ & $\mathbf{B}$ \\
\hline Constant & & & $\mathbf{0 . 2 1 5}$ \\
Audit Committee (AC) & $\mathbf{0 . 0 9 3}$ & $\mathbf{0 . 0 0 8 6}$ & $\mathbf{0 . 2 0 3}$ \\
Foreign Ownership (FO) & $\mathbf{- 0 . 1 0 1}$ & $\mathbf{0 . 0 1 0 2}$ & $\mathbf{- 0 . 0 8 3}$ \\
Size & $\mathbf{0 . 6 0 9}$ & $\mathbf{0 . 3 7 0 9}$ & $\mathbf{0 . 2 1 1}$ \\
Leverage & $\mathbf{- 0 . 2 6 5}$ & $\mathbf{0 . 0 7 0 2}$ & $\mathbf{- 0 . 1 0 9}$ \\
Independent Commission (IC) & $\mathbf{- 0 . 0 3 7}$ & $\mathbf{0 . 0 0 1 4}$ & $\mathbf{- 0 . 1 1 0}$ \\
\hline
\end{tabular}

$\mathrm{R}$ (simultaneously) $=0,655$

Source: SPSS output

The first hypothesis states that audit committees have a positive effect on sustainability report. The results of this study indicate that the audit committee was not proven to influence sustainability report in mining sector companies listed on the Indonesia Stock Exchange. The results of this study are not in line with the research conducted by Said et al (2017); Said et al (2009); Khan et al (2013); Jizi et al (2014); Kend (2015) which states that the audit committee has a positive effect on sustainability report. But the results of this study are in line with research conducted by Appuhami and Tashakor (2017) which states that audit committees have no effect on sustainability report. The audit committee's influence on sustainability report in mining companies that are listed on the Indonesia Stock Exchange is due to the existence of an audit committee only because of regulatory incentives in order to avoid sanctions and not intended to enforce corporate governance (Sodiq in Makhdalena, 2012). This can be seen from the research data where the average number of audit committee members from the sample companies is only 3 people at the minimum, and there are even sample companies that only have two audit committees. OJK (2015) requires the composition of the audit committee, namely a minimum of three (3) people. And there are also sample companies that do not have financial experts on the audit committee. OJK (2015) requires audit committee members at least one (1) person to be a financial expert. Audit committee members also do not have experts who are socio-certified and environmental, so they do not understand the concept of sustainability itself. Furthermore, the audit committee's impact on sustainability report was also caused by the lack of audit committee activities. This can be seen from the research data where the number of meetings held by audit committees from sample companies was only fulfilling regulatory requirements and even sample companies. the audit committee does not conduct meetings. According to OJK (2015) the audit committee must hold meetings at least one (1) time in three (3) months. Lastly, this audit committee did not influence the sustainability report because the audit committee did not work full-time at the companies that appointed them so they did not have much time to discuss matters related to sustainability. SOA (2002) requires an audit committee to work full-time with companies that appoint them to be able to pay close attention to everything related to corporate governance because corporate governance is the responsibility of the audit committee.

The second hypothesis of this study is: Foreign ownership has a positive effect on sustainability report. However, based on the results of the study, it can be seen that foreign ownership has a negative effect on sustainability reporti The results of this study are not in line with the research conducted by Said et al (2009), Khan et al (2013), Oh et al (2011), Saleh et al (2010), Soliman et al (2013), Darus et al (2009) and Guinness et al (2017) which state that foreign ownership has a positive effect on sustainability report. The results of this study are in line with the research conducted by Zulvina et al (2017) which states that foreign ownership has a negative effect on sustainability report. Foreign ownership has a negative effect on sustainability report in mining sector companies listed on the Indonesia Stock Exchange. This is because the investment costs for implementing sustainability are very expensive and the return time for these investments are very long. As a result, the costs incurred to implement sustainability will reduce the profits that will be distributed as dividends to shareholders (foreign ownership). As the mining sector is a non-renewable natural resource sector, the company operates only as long as the mining stock is still available, so the company is reluctant to apply sustainability. This makes the companies become 
unwilling to implement sustainability. Or if they do, the sustainability program that is carried out is only philanthropy. This can be seen from the results of research data where the average sustainability disclosure is only at index 32 or $32 \%$ of the total items that must be done. There are even sample companies that only disclose $4.55 \%$ of the total items that should be disclosed. The highest number of sample companies revealed that sustainability items were $68.18 \%$. The low implementation of sustainability is due to the absence of clear and explicit punishment for companies whom do not carry out sustainability so that the disclosure is low.

\section{Conclusion}

Based on the formulation of the problem, review of the literature and the results of the research and discussion, it can be concluded that the audit committee has no effect on the sustainability report and foreign ownership has a negative effect on sustainability report.

\section{References}

Appuhami. R and Tashakor Shamim (2017). The Impact of Audit Committee Characteristics on CSR Disclosure: An Analysis of Australia Firms. Australian Accounting Review. 27 (4) pp: 400-420.

Berle, JE, AA dan G. C. Means (1932). The modern Corporation and Private Property. Macmillan, New York.

Darus. F, Arshad R, Othman S (2009). Influence of Institutional Pressure and Ownership Structure on Corporate Social Responsibility Disclosure. Interdisciplinary Journal Of Contemorary Research in Business Vol. 1 (5), p: $123-150$

Elkington, John (1997). Cannibals with Forks: The Triple Bottom Line of 21st Century Business. Oxford.

Guinness PB, Vieito JP, Wang M. (2017). The role of board gender and foreign ownership in the CSR performance of Chinese listed firms. Journal of Corporate Finance, 42, p: 75-99

Jizi. M. I, Salama. A, Dixon R. and Stratling R (2014). Corporate Governance and Corporate Social Responsibility Disclosure: Evidence from the US Banking Sector. J Bus Ethics. 125, p: 601-625.

Kend, Michael. 2015. "Governance, firm-level characteristics and their imoact on the client's voluntary sustainability disclosures and assurance decisions". Sustainability Accounting, Management and Policy Journal, Vol.6, No. 1, pp. 54-78

Khan A, M. B. Muttakin and Siddiqui J (2013). Corporate Governance and Corporate Social Responsibility Disclosure: Evidence from an Emerging Economy. Journal Business Ethics 114, p: 207-223.

Makhdalena (2012). Pengaruh Proporsi Komisaris Independen dan Komposisi Komite Audit terhadap Earnings Management (Studi pada Perusahaan Konglomerasi yang Listing di Bursa Efek Indonesia).Jurnal Akuntansi. Vol. XVI/03, p: 336-349

Messier, Jr., Glover, William F., Prawitt, Steven M., dan F., Douglas. 2006. Jasa Audit dan Assurance: Pendekatan Sistematis, Edisi 4, Buku 1. Penerbit Salemba Empat: Jakarta.

Oh, W.Y., Chang, Y.K., \&Martynov, A (2011). The effect of ownership structure on corporate social responsibility: Empirical evidence from Korea. Journal of Business Ethics, 104, 283-297.

Otoritas Jasa Keuangan. 2015. Peraturan Otoritas Jasa Keuangan Nomor 55/ POJK 04/ 2015 tentang Pembentukan dan Pedoman Pelaksanaan Kerja Komite Audit.

Said Roshima, Yuserrie and HasnahHarun (2009). The relationship between corporate social responsibility disclosure and corporate governance characteristics in Malaysian public listed companies. Social Responsibility Journal. Vol. 6 No. 2, p: 212-226.

Said. R., Joseph. C., Sidek. N. Z. M (2017). Corporate Governance and Corporate Social Responsibility (CSR) disclosure: The Moderating Role of Cultural Values. Modern Organisational Governance. Vol. 12, pp 189206.

Saleh M, Zulkifli N dan Muhammad R (2010). Corporate social responsibility disclosure and its relation on institutional ownership: Evidence from public listed companies in Malaysia. Managerial Auditing Journal. Vol. 25 (6), p: 591-613.

SASB. 2014. Metals \& Mining Sustainability Accounting Standard. San Fransisco, www.sasb.org

Sarbanes-Oxley Act of 2002 (Sarbox), An Act., 107th Congress USA

Soliman M, M Bahaa El Din, A Sakr (2012). Ownership Structure and Corporate Social Responsibility (CSR): An Empirical Study of the Listed Companies in Egypt. The International Journal of Social Sciences. Vol. 5 No. 1.p: 63-74.

Tempo, 18 Maret 2017

Zulvina, Fitri, Desi Zulvina, Yani Zulvina, and Makhdalena (2017). Ownership Structure, Independent Commissioner, and Corporate Social Responsibility. Research Journal of Finance and Accounting, Vol. 8, No, 22, pp:111-118.

https://www.liputan6.com

https://www.tempo.com

https://www.reuters.com 


\section{Frequencies}

\begin{tabular}{|c|c|c|c|c|c|c|c|c|c|c|c|c|c|}
\hline \multicolumn{14}{|c|}{ Descriptive Statistics } \\
\hline & \multirow{2}{*}{$\begin{array}{c}\text { N } \\
\text { Statistic }\end{array}$} & \multirow{2}{*}{$\begin{array}{l}\text { Range } \\
\text { Statistic }\end{array}$} & \multirow{2}{*}{\begin{tabular}{|l|} 
Minimum \\
Statistic \\
\end{tabular}} & \multirow{2}{*}{\begin{tabular}{|c} 
Maximum \\
Statistic \\
\end{tabular}} & \multirow{2}{*}{$\begin{array}{c}\text { Sum } \\
\text { Statistic }\end{array}$} & \multicolumn{2}{|c|}{ Mean } & \multirow{2}{*}{$\begin{array}{c}\text { Std. } \\
\text { Deviation } \\
\\
\text { Statistic }\end{array}$} & \multirow{2}{*}{\begin{tabular}{|l|} 
Variance \\
Statistic \\
\end{tabular}} & \multicolumn{2}{|c|}{ Skewness } & \multicolumn{2}{|c|}{ Kurtosis } \\
\hline & & & & & & Statistic & Std. Error & & & Statistic & $\begin{array}{l}\text { Std. } \\
\text { Error }\end{array}$ & Statistic & $\begin{array}{l}\text { Std. } \\
\text { Error }\end{array}$ \\
\hline KI & 36 & 30.00000 & 30.00000 & 60.00000 & 1369.81685 & 38.0504680 & 1.28354063 & 7.70124378 & 59.309 & 1.121 & .393 & .419 & .768 \\
\hline KA & 36 & 15.00000 & 6.00000 & 21.00000 & 508.00000 & 14.1111111 & .56593479 & 3.39560874 & 11.530 & .233 & .393 & .013 & .768 \\
\hline Foreign & 36 & 86.90000 & 10.10000 & 97.00000 & 1856.65000 & 51.5736111 & 4.49617896 & 26.97707377 & 727.763 & .043 & .393 & -1.383 & .768 \\
\hline Size & 36 & 85676500 & 261439 & 85938000 & 543878000 & 15107734 & 3449157.07 & 20694942.4 & $\begin{array}{r}428300000 \\
000000\end{array}$ & 2.060 & .393 & 4.104 & .768 \\
\hline Lev & 36 & 40.40200 & .16000 & 40.56200 & 125.33900 & 3.4816389 & 1.59698833 & 9.58193001 & 91.813 & 3.541 & .393 & 11.945 & .768 \\
\hline SusReport & 36 & 63.63636 & 4.54545 & 68.18182 & 1154.54545 & 32.0707071 & 2.53497407 & 15.20984443 & 231.339 & .404 & .393 & -.611 & .768 \\
\hline $\begin{array}{l}\text { Valid N } \mathrm{N} \\
\text { (listwise) }\end{array}$ & 36 & & & & & & & & & & & & \\
\hline
\end{tabular}

\begin{tabular}{|c|c|c|c|c|c|c|c|c|c|c|c|c|c|}
\hline \multicolumn{14}{|c|}{ Descriptive Statistics of Audit Committe } \\
\hline & \multirow{2}{*}{\begin{tabular}{|c|}
$\mathrm{N}$ \\
Statistic \\
\end{tabular}} & \multirow{2}{*}{$\begin{array}{c}\text { Range } \\
\text { Statistic }\end{array}$} & \multirow{2}{*}{\begin{tabular}{|l|} 
Minimum \\
Statistic \\
\end{tabular}} & \multirow{2}{*}{\begin{tabular}{|c|} 
Maximum \\
Statistic \\
\end{tabular}} & \multirow{2}{*}{$\begin{array}{c}\text { Sum } \\
\text { Statistic } \\
\end{array}$} & \multicolumn{2}{|c|}{ Mean } & \multirow{2}{*}{$\begin{array}{c}\text { Std. } \\
\text { Deviation } \\
\text { Statistic }\end{array}$} & \multirow{2}{*}{\begin{tabular}{|l|} 
Variance \\
Statistic \\
\end{tabular}} & \multicolumn{2}{|c|}{ Skewness } & \multicolumn{2}{|c|}{ Kurtosis } \\
\hline & & & & & & Statistic & Std. Error & & & Statistic & $\begin{array}{l}\text { Std. } \\
\text { Error }\end{array}$ & Statistic & $\begin{array}{l}\text { Std. } \\
\text { Error }\end{array}$ \\
\hline AC_SIZE & 36 & 2.00000 & 2.00000 & 4.00000 & 107.00000 & 2.9722222 & .04856858 & .29141145 & .085 & -.919 & .393 & 10.377 & .768 \\
\hline AC_IND & 36 & 2.00000 & 2.00000 & 4.00000 & 105.00000 & 2.9166667 & .06139903 & .36839420 & .136 & -1.084 & .393 & 4.465 & .768 \\
\hline AC_EXP & 36 & 3.00000 & .00000 & 3.00000 & 64.00000 & 1.7777778 & .14426118 & .86556707 & .749 & -659 & .393 & .084 & .768 \\
\hline AC_MEET & 36 & 13.00000 & .00000 & 13.00000 & 232.00000 & 6.4444444 & .50307695 & 3.01846171 & 9.111 & .688 & .393 & .068 & .768 \\
\hline $\begin{array}{l}\text { Valid } \quad \mathrm{N} \\
\text { (listwise) }\end{array}$ & 36 & & & & & & & & & & & & \\
\hline
\end{tabular}

\section{Model Summary ${ }^{b}$}

\begin{tabular}{|l|r|r|r|c|}
\hline Model & \multicolumn{1}{|c|}{$\mathrm{R}$} & R Square & \multicolumn{1}{|c|}{$\begin{array}{c}\text { Adjusted R } \\
\text { Square }\end{array}$} & $\begin{array}{c}\text { Std. Error of the } \\
\text { Estimate }\end{array}$ \\
\hline 1 & $.809^{\mathrm{a}}$ & .655 & .598 & .35167661 \\
\hline
\end{tabular}

a. Predictors: (Constant), LN_IC, LN_FOR, LN_AC, LN_SIZE, LN LEV

b. Dependent Variable: LN_SUSREPORT

\section{ANOVA}

\begin{tabular}{|ll|r|r|r|r|r|}
\hline Model & & Sum of Squares & Df & Mean Square & F & Sig. \\
\hline 1 & Regression & 7.049 & 5 & 1.410 & 11.399 & $.000^{\mathrm{a}}$ \\
& Residual & 3.710 & 30 & .124 & & \\
& Total & 10.759 & 35 & & & \\
\hline
\end{tabular}

a. Predictors: (Constant), LN_IC, LN_FOR, LN_AC, LN_SIZE, LN_LEV

b. Dependent Variable: LN_SUSREPORT 


\section{Coefficients $^{\mathrm{a}}$}

\begin{tabular}{|c|c|c|c|c|c|c|}
\hline \multirow{2}{*}{\multicolumn{2}{|c|}{ Model }} & \multicolumn{2}{|c|}{ Unstandardized Coefficients } & \multirow{2}{*}{$\begin{array}{c}\text { Standardized } \\
\text { Coefficients }\end{array}$} & \multirow[b]{2}{*}{$\mathrm{t}$} & \multirow[b]{2}{*}{ Sig. } \\
\hline & & $\mathrm{B}$ & Std. Error & & & \\
\hline \multirow[t]{6}{*}{1} & (Constant) & .215 & 1.563 & & .137 & .892 \\
\hline & LN_AC & .203 & .261 & .093 & .776 & .444 \\
\hline & LN_FOR & -.083 & .093 & -.101 & -.889 & .381 \\
\hline & LN_SIZE & .211 & .042 & .609 & 4.972 & .000 \\
\hline & LN_LEV & -.109 & .053 & -.265 & -2.063 & .048 \\
\hline & LN_IC & -.110 & .358 & -.037 & -.308 & .760 \\
\hline
\end{tabular}

a. Dependent Variable: LN_SUSREPORT 